\title{
Constraints in sustainable smallholder rubber farming in the Moneragala district
}

\author{
Wasana Wijesuriya*, D M A P Disssanayake*, H M L K Herath** and \\ P K K S Gunaratne* \\ * Rubber Research Institute of Sri Lanka, Dartonfield, Agalawatta, Sri Lanka \\ **Wayamba University of Sri Lanka, Makandura, Gonawila (NWP), Sri Lanka
}

Received 16 January 2012; Accepted 24 February 2012

\begin{abstract}
This study was focused on the Moneragala district which is one of the districts in the Uva Province. Rubber cultivation, being a new initiative there is a high risk of resource wastage in these areas which necessitated a detail study for proper planning of this exercise. Hence, the objective of this study was to assess the existing status of rubber cultivation in this area together with socio-economic conditions of rubber farmers. A questionnaire survey was done to collect relevant information from 255, 248 and 143 respondents in the respective categories of farmers who are prepared to cultivate rubber (potential farmers) and those who own immature and mature rubber plantations. Participatory studies were also done to assess the awareness on technical recommendations of rubber. The technical efficiency of rubber farmers was studied employing a stochastic frontier approach.

More than 50\% of the farmers had only primary level education. Hence, education needs to be considered as a constraint in improving the awareness of rubber farmers. Higher percentage of farmers with a monthly income of less than Rs. 10,000 should also be regarded as a bottleneck for the adoption of recommended technologies. Awareness on recommendations in immature phase ranged from $19 \%$ to $55 \%$ which was not at a satisfactory level. The awareness on tapping related activities was also not adequate since the awareness scores for both general and technical knowledge on tapping were below $40 \%$.

The production efficiency levels of mature rubber lands ranged from 17\% to 96\%, with an average value of 59\%. The lands with smaller extent have lower efficiency levels. Those who practice the recommended tapping intensity had high efficiency levels. The average efficiency observed in the virgin panel was $62 \%$ while it was $52 \%$ with the renewed panels. The average efficiency in the lands tapped by owners themselves was $61 \%$ while when tappers were hired it was only $55 \%$.
\end{abstract}

Key words: efficiency analysis, non-traditional areas, smallholders, sustainable rubber farming 


\section{Introduction}

Increasing productivity and extent under cultivation are the two possible solutions to achieve the national targets in the rubber sector. However, declining rubber extent is an issue of national concern in Sri Lanka. The rubber extent in late 1970s, which was recorded above 200,000 ha, reduced drastically since 2002 to 114,000 ha. This is mainly due to change in land use that took place in traditional rubber growing areas particularly in the wet zone of Sri Lanka. Further, new planting programmes in these areas remain at a very low level due to nonavailability of land. The state response towards this issue was a very positive one, giving emphasis on non-traditional rubber growing areas in Uva and Eastern provinces where land and labour are assumed to be non-limiting factors.

The nontraditional rubber growing areas have been focused in many development projects aiming the rural poor but with very little prospective results. There is some obvious evidence since Uva province is still the poorest with poverty Head Count Index ${ }^{1}$ (HCI) of $27 \%$ while Moneragala and Badulla districts have HCIs of $33.2 \%$ and $23.7 \%$, respectively and being ranked as $2^{\text {nd }}$ and $4^{\text {th }}$ districts based on this index (Anon, 2009). With this background, there is a risk of resource wastage unless proper planning is done at the initial stages of rubber

\footnotetext{
${ }^{1}$ Size of poor population fall underneath the poverty line

development programmes in these areas. This is especially important in development of the smallholder sector where resource wastage is expected to be more due to poor awareness and adoption of technical recommendations related to rubber planting and processing. Further, many development programmes have failed due to insufficient attention on the needs and thoughts of the community, in the planning process.

Being a new initiative, there is a high degree of uncertainty about the sustainability of the attempt on expanding rubber into non-traditional areas due to inadequacy in knowledge on environmental, socio-economic, technological and institutional aspects. This necessitated a detail study of the above issues. This study was focused on smallholder rubber farmers in the Moneragala district with the main objective of identifying the issues and perspectives of them to rectify inadequacies in knowledge on environmental, social, economic, technological and institutional aspects which appear in different magnitudes.

\section{Materials and Methods Description of the study area}

Rubber is found in 8 out of 11 Divisional Secretariat (DS) divisions in the Moneragala district. This study covered 7 DS divisions in Moneragala district. Data from Dombagahawela which represented the DS division, Siyambalanduwa was removed from analysis due to lack of data. 
Wasana Wijesuriya et al.

\section{Participatory rural appraisal}

Participatory studies were designed to investigate socio-economic, environmental and technological aspects and were carried out during 2007 and 2008. Testing awareness on recommendations was done through 'pocket voting'. In this exercise, the farmers read questions one by one and selected the answer and then voted for it by inserting a small card to the relevant envelope. The farmers were categorized into stage of their cultivation (immature or mature) by giving cards of different colours. Finally for each question, the correct answers were counted for each category and awareness on recommendations was calculated as a percentage.

The recommendations were categorized into; a) planting related activities, b) soil fertility management, c) crop upkeep, d) general knowledge on tapping and e) technical knowledge on tapping. To test awareness, the potential rubber growers were sent for questions from (a) to (c) and farmers who own immature and mature holdings were for all categories. The questions under each category are listed in Tables 1 and 2.

Table 1. Questions tested for awareness on agronomic recommendations

\begin{tabular}{ll}
\hline Category & Tested areas of awareness \\
\hline Planting related activities & 1. Measures to be taken up in replanting \\
& 2. Recommended clones for smallholders \\
3. Recommended trees per ha. \\
4. Recommended spacing \\
5. System of planting in a slopy area \\
6. Recommended Size of planting hole \\
7. Main reason for elephant foot formation in trunk \\
Maintenance of immature fields & 1. Pruning of side shoots \\
& 2. Branch induction \\
3ntercropping & 1. Mulching around the tree \\
1. Correct spacing for rubber with intercrops \\
2. Types of intercrops used under rubber \\
1. Treatment for white root disease \\
2. Reasons for tapping panel dryness (TPD) \\
1. Application of urea based mixture with Dolomite \\
2. Fertilizer application for mature rubber \\
3. Method of fertilizer application \\
4. Soil conservation in a sloppy land \\
5. Soil fertility \& ground cover management
\end{tabular}


Constraints in smallholder rubber farming in Moneragala

Table 2. Questions tested for awareness on recommendations related to tapping

\begin{tabular}{lcl}
\hline Category & Tested areas of awareness \\
\hline General awareness on tapping & 1. & Required number of tappable trees to \\
& commence tapping \\
2. & Required girth at tapping \& height of \\
& measurement \\
3. & Cup hanging \\
4. & Time of tapping \\
5. & Sharpening of tapping knife \\
Technical awareness on tapping & 1. Height of tapping panel \\
& 2. Angle of tapping \\
3. Tapping panel marking \\
4. Tapping system \\
5. Depth of tapping \\
6. Thickness of tapping \\
7. Frequency of tapping for new clones \\
\hline
\end{tabular}

Questionnaire survey

Questionnaires were designed to gather information falling into socio-economic, environmental, technological and institutional aspects of the smallholder rubber sector. Three questionnaires were prepared to collect information on household details of those who expect to start rubber cultivation and those who own immature and mature rubber lands. Stratified random sampling was employed based on the existing and authorized rubber plantations in DS divisions. This paper is based on the information gathered from all the farmers surveyed. A total of 255, 248 and 143 rubber farmers were interviewed during the study in 2008 under the respective categories of potential, immature and mature conditions.

\section{Analysis of data}

The information gathered from the questionnaire survey was analyzed using descriptive methods. The software FRONTIER 4.1 was used to estimate efficiency values and determinants of efficiency jointly as described by Coelli (1996). The 'zeros' in the Cobb-Douglas model was handled as described by Battese (1997). The following variables were used to develop the production frontier with latex production $(\mathrm{kg} / \mathrm{ha} / \mathrm{yr})$ as the dependent variable. 
Wasana Wijesuriya et al.

\author{
TAPTREES No. of tappabale trees per ha \\ DIFERT Dummy for amount of fertilizer applied (kg/year) (used to avoid the \\ problem of zeros) \\ FERTAMT Fertilizer applied (kg/year) \\ AGEPLANT Age of plantation (years)
}

Rest of the variables; viz.farm and farmer specific factors used in the analysis which may affect efficiency are listed below.
EXT
Extent of land (ha)
TAPINT
Dummy for tapping intensity (1-recommended method, 0-otherwise)
PANEL
Tapping panel (1-virgin bark, 0 -otherwise)
$H I R E D L A B \quad$ Labour for other activities (1-hired, 0-family only)
TAPLAB $\quad$ Labour for tapping (1-family, 0-hired)
DIST Distance from home $(\mathrm{km})$
$A G E \quad$ Age of smallholder (years)
$D A L \quad$ Dummy for education (1- If $\mathrm{A} / \mathrm{L}$ and higher, 0-otherwise)
$D O L \quad$ Dummy for education (1- If $\mathrm{O} / \mathrm{L}$ and higher, 0-otherwise)
$F A M L A B \quad$ Labour involvement from family (number)
DCLREC Dummy for recommended clone (1-recommended clone, 0-otherwise)

\section{Results and Discussion \\ Socio-economic characteristics of rubber smallholders}

The key socio-economic characteristics of smallholder farmers are given in Table 3. There was an indication of the younger generation's preference for rubber cultivation in these areas as the proportion under 50 years of age, is more under categories of 'potential' and farmers who own immature holdings compared to farmers who own mature holdings. The education levels of the smallholders were categorized into (1) Primary (2) Ordinary level qualified (3) Advanced Level qualified or higher. More than $50 \%$ of the farmers had only primary level education. This needs to be considered as a constraint in improving the awareness of rubber farmers in the non-traditional rubber growing areas. The higher percentage with a monthly income of less than Rs.10,000 should also be regarded as a bottleneck for the adoption of recommended technologies and proper monitoring methodologies need to be adopted in disbursement of subsidies to ensure proper use of state funds. The improvement in economic status is evident in the 'mature' category, as a higher proportion of farmers were observed to be above the monthly income level of Rs.25,000 compared to 'potential' and 'immature' categories.

'Thurusaviya' is the farmer organization in operation in the Moneragala area. There was a good indication on societal involvement by 'potential' farmers since $21 \%$ of the sample had already taken memberships in this organization even before cultivating rubber. Twenty seven percent of farmers who own immature plantations are members of Thurusaviya. 
Constraints in smallholder rubber farming in Moneragala

Table 3. Key socio-economic characteristics of smallholder farmers

\begin{tabular}{lccc}
\hline Characteristic & \multicolumn{3}{c}{ Categories surveyed } \\
\cline { 2 - 4 } & $\begin{array}{c}\text { 'Potential' } \\
\text { rubber } \\
\text { farmers }\end{array}$ & $\begin{array}{c}\text { Farmers own } \\
\text { immature } \\
\text { fields }\end{array}$ & $\begin{array}{c}\text { Farmers own } \\
\text { mature fields }\end{array}$ \\
\hline Size of household & $\begin{array}{c}\text { Range: } 1-8 \\
\text { Average: } 4\end{array}$ & $\begin{array}{c}\text { Range: } 1-10 \\
\text { Average: } 5\end{array}$ & $\begin{array}{c}\text { Range: } 1-10 \\
\text { Average: } 5\end{array}$ \\
\hline \% female smallholders & 22 & 18 & 13 \\
\hline Age structure (\%) & & & \\
Under 40 years & 34 & 27 & 21 \\
40-49 years & 35 & 34 & 26 \\
50-59 years & 26 & 26 & 31 \\
60 \& above & 5 & 13 & 22 \\
\hline Level of education (\%) & & & 0 \\
No schooling & 2 & 0 & 54 \\
Primary & 51 & 60 & 34 \\
Ordinary level (OL) & 36 & 32 & 12 \\
Advanced level (AL) \& higher & 15 & 8 & 46 \\
\hline Monthly income (\%) & & & 17 \\
<Rs. 10000 & 57 & 70 & 13 \\
Rs. 10001-25000 & 31 & 29 & \\
Rs. 25001-50000 & 10 & 1 & \\
>Rs. 50000 & 2 & - & \\
\hline
\end{tabular}

Farmers of mature plantations have taken great interest on the societies as $46 \%$ hold memberships. However, promotional campaigns on the importance of societal arrangements in different operations in rubber farming, especially marketing need to be arranged to improve the membership.

\section{Awareness on recommendations}

Awareness on recommendations of the immature phase

The awareness scores of different activities in immature stage in the villages are listed in Table 4 . The awareness on maintenance of immature lands was found to be the lowest in the villages tested with an average of $21 \%$. Awareness on disease control was also poor indicating an average of $34 \%$. Awareness on other 3 activities; viz. planting related activities, intercropping and soil fertility management was moderate, $49 \%, 45 \%$ and $50 \%$, respectively in the selected villages. Awareness buildup on immature upkeep is a necessity in all selected sites since no score above $60 \%$ was recorded in any of the sites. 
Awareness on recommendations on tapping related activities

Awareness scores of general and technical knowledge on tapping generated through questions in different villages are listed in Table 5. The awareness on tapping related activities is not adequate in general since the average awareness scores for both general and technical knowledge on tapping were below $40 \%$.

Table 5. Awareness on general and technical knowledge on tapping

\begin{tabular}{llcc}
\hline \multirow{2}{*}{ DS Division } & Village & \multicolumn{2}{c}{ \% awareness on tapping } \\
\cline { 2 - 4 } Badalkumbura & Hela Thunkala & General knowledge & Technical knowledge \\
& Lunugala Kolaniya & 40 & 19 \\
& Kotamuduna & 14 & 38 \\
& Karawila & 47 & 2 \\
& Karandagama & 17 & 52 \\
& Madugahapattiya & 56 & 15 \\
& Pitakumbura & 32 & 67 \\
\hline Bibile & Radaliedda & 16 & 33 \\
& Badullagammana & 39 & 13 \\
Buttala & Yudaganawa & 13 & 42 \\
\hline Madulla & Kolladeniya & NA & 9 \\
\hline Medagama & Rattanadeniya & 46 & NA \\
& Polgahapitiya & 58 & 45 \\
\hline Moneragala & Tenagallanda & 57 & 65 \\
& Batugammana & 59 & 50 \\
& Tanwatta & 63 & 52 \\
\hline Wellawaya & Siyabalagune & 30 & 62 \\
\hline \multirow{2}{*}{} & Average & 38 & 36 \\
& Min & 14 & 38 \\
& Max & 63 & 67 \\
\hline
\end{tabular}

$N A$ - Respondents not enough for the study 
Wasana Wijesuriya et al.

\section{Status of immature and mature lands}

In immature holdings, the recommended plants per ac. (500 plants/ha) reduced to an average of 427 per ha. due to various reasons. Impact of droughts was the most prominent with an average of $67 \%$ and $14 \%$ of the sample stated that poor quality plants provided to them was the cause for the death of plants. Intercrops are grown in $79 \%$ of the immature rubber lands. Cover crop is not present in $97 \%$ of the immature lands. Stone terraces are present in $37 \%$ of the fields while drains are present in $23 \%$ of the immature lands. Regular weed control is practiced in $98 \%$ of the immature holdings. All the farmers applied fertilizer that was supplied to them through the subsidy. Fertilizer application was done in $78 \%$ of the holdings, leaving $22 \%$ of non adopters. Method of application was according to the recommendation in $60 \%$ of the holdings, while $32 \%$ applied fertilizer around the trees.

In mature rubber plantations, the majority of the farmers $(53 \%)$ did not know about the clone in their field. Clone RRIC 100 was found in $23 \%$ of the lands and $17 \%$ of the lands were planted with $\mathrm{PB} 86$. The remaining extent was occupied by RRIC 121 and RRIC 102. The number of trees at present reduced to an average of 414 trees/ha compared to 488 trees/ha planted per ha. during establishment of the rubber field. Further, the tappable trees reduced to an average of 368 trees/ha due to various reasons. Drought was the main cause for the reduced stand per ha. The other important reasons were poor quality of plants, animal and fire damages and tapping panel dryness (TPD). Different types of intercrops are present in 35\% of the mature holdings. Among them, Cocoa and Banana were the most popular while pepper, sugarcane and cinnamon are present in several fields. Diseases or disorders were not identified in $44 \%$ of the holdings reported with diseases. In $38 \%$ of the holdings tapping panel dryness was observed and white root disease was present in $19 \%$ of the holdings. Fertilizer application was not done in $54 \%$ of the mature holdings. Method of application was according to the recommendation in $57 \%$ of the holdings, while $8 \%$ applied fertilizer around the trees.

\section{Major issues of rubber farmers}

The majority of the respondent farmers in participatory studies were 'potential' rubber growers who had already received permits for rubber cultivation and were expecting to cultivate rubber. Hence, the major issues in most of the areas were related to planting material. Due to the high demand for planting material, poor quality planting material have been released to the farmers in certain occasions. Some farmers have raised the issue of difficulty in getting permits for rubber cultivation, as they had not received permits from Divisional Secretariats for cultivation (Nearly 53\% of the survey sample stated that they occupy state owned land on lease or having 'Swarnabhoomi' or 'Jayabhoomi' deeds and some are 
encroachers). Further, delay in subsidy payments, poor knowledge on rubber farming, marketing problems and lack of training facilities were also found as major issues in some areas.

\section{Efficiency levels of mature farming units}

The production efficiency levels estimated using the Cobb-Douglas production frontier ranged from $17 \%$ to $96 \%$, with an average value of $59 \%$. This suggests that $41 \%$ of the potential maximum productivity is lost due to inefficiency of farmers in the Moneragala district. Nearly $48 \%$ of the sample is observed above the average value of $59 \%$. Relatively a higher percentage of farmers (14.6\%) were observed in the efficiency range of $81 \%$ to $90 \%$. About $6 \%$ of the farmers were above the $90 \%$ efficiency level.

The effect of farm and farmer specific factors on inefficiency was simultaneously estimated with the production frontier. Among the variables used in the analysis, tapping panel (PANEL), labour for tapping (TAPLAB) and dummy for education (DOL) were significant at the probability level of 0.01 while extent of land (EXT), intensity of tapping (TAPINT) were significant at 0.05 probability level (Table 6).

The extent of land (EXT) had a significant estimate with a negative sign, which suggested that higher the efficiency with higher the extent. The lands with extents less than 1.5 ha had efficiency values of $59 \%$ while an average efficiency of $71 \%$ was observed in lands with extents greater than 1.5ha. Tapping intensity (TAPINT) is another important variable which affects productivity. This variable also returned a significant negative estimate (Table 6). Those who practice the recommended level had high efficiency levels. The average efficiency obtained by practicing recommended tapping intensity was $60 \%$ while those who do not practice the recommendation had an efficiency level of $43 \%$. Tapping panel (PANEL) also had a significant negative estimate (Table 6) depicting those who tap on the virgin panel (A \& B) have higher efficiency levels. The average efficiency observed in the virgin panel was $62 \%$ while it was $52 \%$ with the renewed panels.

Hiring of labour (a dummy, 1 for hired labour and 0 for family labour only) had no effect on the efficiency. However, the dummy for labour for tapping (TAPLAB), 1 for family and 0 for hired was found to be significant with a negative sign, suggesting that those who tap their own land have higher efficiencies with respect to production. The average efficiency in the lands tapped by owners themselves was $61 \%$ while when tappers were hired it was only $55 \%$. Distance and age of farmers did not have any significant effect on the efficiency. Further family labour involvement (the number) and the dummy for the recommended clones were found to be non-significant (Table $6)$. 
Wasana Wijesuriya et al.

Table 6. Determinants of production inefficiency according to the stochastic Cobb-Douglas frontier

\begin{tabular}{lrrrr}
\hline Variable & Coefficient & Standard error & t- ratio & \\
\hline Constant & 0.936 & 0.652 & 1.436 & $*$ \\
EXT & -0.097 & 0.065 & -1.491 & $*$ \\
TAPINT & -0.476 & 0.300 & -1.587 & $*$ \\
PANEL & -0.344 & 0.185 & -1.859 & $* *$ \\
HIREDLAB & 0.027 & 0.125 & 0.216 & \\
TAPLAB & -0.279 & 0.162 & -1.722 & $* *$ \\
DIST & 0.029 & 0.036 & 0.806 & \\
AGE & 0.002 & 0.005 & 0.404 & \\
DAL & 0.070 & 0.210 & 0.333 & \\
DOL & -0.314 & 0.169 & -1.855 & $* *$ \\
FAMLAB & 0.011 & 0.040 & 0.275 & \\
DCLREC & 0.484 & 0.603 & 0.802 & \\
\hline
\end{tabular}

*** indicate 0.05 and 0.01 levels of significance

Dummy for education (1- If $\mathrm{O} / \mathrm{L}$ and higher, 0-otherwise) returned a negative significant estimate as expected. Those who have an education level above $\mathrm{O} / \mathrm{L}$ have an average efficiency value of $62 \%$ while those who do not have an average of $57 \%$. For achieving production efficiency, reallocation of resources with changing economic conditions is vital. Education provides this by enabling the farmers to (a) perceive that a change has occurred (b) collect, retrieve and analyze useful information (c) drawing valid conclusions from available information and (d) act quickly and decisively (Abdulai and Huffman, 2000). This also is in line with other similar studies such as Basnayake and Guneratne
(2001) in tea smallholding sector of Sri Lanka, Ali and Flinn (1989) for rice production in Pakistan and Edirisinghe and Wijesuriya (2010) for rubber in Sri Lanka.

\section{Conclusions}

The production efficiency levels of mature rubber lands ranged from 17\% to $96 \%$, with an average value of $59 \%$. This suggests that $41 \%$ of the potential maximum productivity is lost due to inefficiency of farmers in the Moneragala district. The lands with smaller extent have lower efficiency levels. Those who practice the recommended tapping intensity had high efficiency levels. The average efficiency observed in the virgin panel 
was $62 \%$ while it was $52 \%$ with the renewed panels. Those who tap their own land had higher efficiency levels. The average efficiency in the lands tapped by owners themselves was $61 \%$ while when tappers were hired it was only $55 \%$. Those who have an education level above Ordinary Level $(\mathrm{O} / \mathrm{L})$ had an average efficiency value of $62 \%$ while those who do not have had an average of $57 \%$.

Awareness on recommendations falling into immature phase in different areas ranged from $19 \%$ to $55 \%$ which was not at a satisfactory level. The awareness on tapping related activities was also not adequate in general since the average awareness scores for both general and technical knowledge on tapping were below $40 \%$. The overall awareness on tapping ranged from $8 \%$ to $63 \%$ in the selected sites. Consequently, poor awareness causes poor adoption of recommendations, a major constraint for sustainable rubber production.

Proper extension programmes need to be carried out in non-traditional areas giving emphasis on poor educational status. Moreover, rigourous monitoring of use of subsidy for rubber farming is vital to minimize resource wastage.

\section{Acknowledgements}

This paper reports findings from a study 'An approach towards sustainable development and economics of the smallholder rubber sector' funded by the National Science Foundation (NSF) under the Coordinated Thematic
Research Programme. Authors gratefully acknowledge the financial support provided by NSF. The extension officers of Advisory Services Department of RRISL and officers attached to Rubber Development Department (RDD) in the Moneragala Regional Office who helped in facilitation and organization of workshops is also acknowledged. A sincere appreciation is extended to smallholder farmers for their unreserved support.

\section{References}

Adbulai, A and Huffman, W (2000). Structural adjustment and economic efficiency of rice farmers in northern Ghana. Economic Development \& Cultural Change, 48, 504-512.

Ali, M and Flinn, J C (1989). Profit efficiency among Basmati rice producers in Pakistan Punjab. American Journal of Agricultural Economics 71(2), 303-310.

Anon (2009). Poverty indicators. Department of Census \& Statistics, Ministry of Finance \& Planning, Sri Lanka.

Basnayake, B M J K and Gunaratne, L H P (2001). Estimation of technical efficiency and it's determinants in the Tea small holding sector in the mid country Wet zone of Sri Lanka. Tropical Agricultural Research 14, 137-150.

Battese, G E (1997). A note on the estimation of Cobb Douglas production function when some explanatory variables have zero values. Journal of Agricultural Economics 48 (2), 250252. 
Wasana Wijesuriya et al.

Coelli, T (1996). A Guide to FRONTIER Version 4.1: A Computer Program for Stochastic Frontier Production and Cost Function Estimation. Armidale, Australia, Centre for Efficiency and Productivity Analysis.

Edirisinghe, J and Wijesuriya, W (2010). Profit efficiency of smallholder rubber farmers in Kegalle, Kalutara and Ratnapura districts, Journal of the
Rubber Research Institute of Sri Lanka 90, 64-77.

Address for correspondence: Dr (Mrs) Wasana Wijesuriya, Biometrician, Rubber Research Institute of Sri Lanka, Dartonfield, Agalawatta, Sri Lanka.

e-mail:wasanaw@sltnet.lk. 